WM'03 Conference, February 23-27, 2003, Tucson, AZ

\title{
VITRIFICATION OF HLW PRODUCED BY URANIUM/MOLYBDENUM FUEL REPROCESSING IN COGEMA'S COLD CRUCIBLE MELTER
}

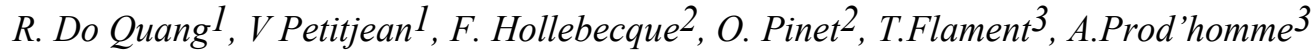 \\ 1 COGEMA, 2 rue Paul Dautier, BP4, 78141 Velizy-Villacoublay Cedex, France \\ Tel: (33) 139263000 Fax: (33) 139262700 \\ 2 CEA Marcoule, BP 171, 30207 Bagnols sur Cèze, France \\ Tel: (33) $466796000 \quad$ Fax: (33) 466791765 \\ 3 SGN, 1 rue des Hérons, 78182 St Quentin Yvelines Cedex, France \\ Tel: (33) $139486691 \quad$ Fax: (33) 139486766
}

\begin{abstract}
The performance of the vitrification process currently used in the La Hague commercial reprocessing plants has been continuously improved during more than ten years of operation. In parallel COGEMA (industrial Operator), the French Atomic Energy Commission (CEA) and SGN (respectively COGEMA's R\&D provider and Engineering) have developed the cold crucible melter vitrification technology to obtain greater operating flexibility, increased plant availability and further reduction of secondary waste generated during operations.

The cold crucible is a compact water-cooled melter in which the radioactive waste and the glass additives are melted by direct high frequency induction. The cooling of the melter produces a solidified glass layer that protects the melter's inner wall from corrosion. Because the heat is transferred directly to the melt, high operating temperatures can be achieved with no impact on the melter itself.

COGEMA plans to implement the cold crucible technology to vitrify high level liquid waste from reprocessed spent U-Mo-Sn-Al fuel (used in gas cooled reactor). The cold crucible was selected for the vitrification of this particularly hard-to-process waste stream because it could not be reasonably processed in the standard hot induction melters currently used at the La Hague vitrification facilities : the waste has a high molybdenum content which makes it very corrosive and also requires a special high temperature glass formulation to obtain sufficiently high waste loading factors (12\% in molybdenum).

A special glass formulation has been developed by the CEA and has been qualified through lab and pilot testing to meet standard waste acceptance criteria for final disposal of the U-Mo waste. The process and the associated technologies have been also being qualified on a full-scale prototype at the CEA pilot facility in Marcoule. Engineering study has been integrated in parallel in order to take into account that the Cold Crucible should be installed remotely in one of the R7 vitrification cell.
\end{abstract}

This paper will present the results obtained in the framework of these qualification programs. 


\section{INTRODUCTION}

Vitrification of high-level liquid waste is the internationally recognized standard to both minimize the impact to the environment resulting from waste disposal and the volume of conditioned waste. Many countries such as the USA, France, the United Kingdom, Germany/Belgium, Japan, Russia, have vitrified high level waste and several more countries are studying application of the vitrification technology.

In France, the vitrification of high-level liquid waste produced from nuclear fuel reprocessing has been successfully operating now for more than 20 years with three major objectives : durable containment of the long-lived fission products, minimization of the final waste volume and operability in an industrial context. As a result, COGEMA ${ }^{1}, \mathrm{CEA}^{2}$ and $\mathrm{SGN}^{3}$ have integrated a unique experience in the field of highlevel waste vitrification through :

- The design and operation of facilities with high records of safety, reliability and product quality, in line with efficient reprocessing plants ;

- The design of various glass formulations including those used in the AVM, R7 and T7 facilities which, together, have produced more than 12,000 glass canisters up to now (corresponding to more than 5 billions $\mathrm{Ci}$ immobilized in 4725 tons of glass);

- Continuous efforts to improve at the same time the technology (from hot to cold crucible) and the associated matrix formulations, with constant emphasis on quality and volume reduction, ended up with the design and qualification of the cold crucible melter (CCM) technology.

Thus, at La Hague, some legacy solutions derived from the reprocessing in the seventies of spent Mo-SnAl fuels in the former UP2-400 plant are still being stored. COGEMA is committed to condition these wastes, which are less radioactive than the current fission product concentrates coming from actual reprocessing activities, but are very rich in molybdenum.

The main features of these solutions called « UMo solutions » are :

- High molybdenum and phosphorus contents : about $90 \mathrm{~g} / 1 \mathrm{MoO}_{3}$ and $15 \mathrm{~g} / 1 \mathrm{P}_{2} \mathrm{O}_{5}$;

- Low activity, less than $80 \mathrm{Ci} / \mathrm{L}$, mainly due to Cesium and Strontium contents and as a consequence a low thermal power about $0.3 \mathrm{~W} / 1$ (to be compared to the current $500 \mathrm{Ci} / 1$ fission products coming from LWR fuel reprocessing and currently vitrified in R7/T7).

Such high amounts of molybdenum cannot be accommodated :

- In the present R7T7 glass formulation, because of the molybdenum effect on long term behaviour properties,

- With standard vitrification technologies due to its unacceptable corrosive power at high temperature.

That is why it has been decided to design a new glass formulation. This calcium and zirconium-enriched alumino-boro-silicate matrix, able to incorporate $12 \%$ of molybdenum oxide, is still corrosive due to its phosphate and molybdenum contents and must be melted at temperatures close to $1300^{\circ} \mathrm{C}$. This process temperature cannot be reached with standard crucible melters, but with Cold Crucible Melter Technology, developped by CEA and COGEMA since the 1980s.

\footnotetext{
${ }^{1}$ Industrial Operator

${ }^{2}$ The French Atomic Energy Commission : COGEMA's R\&D and R\&T provider

${ }^{3}$ COGEMA's Engineering
} 
This technology benefits from the 20 years of COGEMA HLW vitrification experience and ensures a virtually unlimited equipment service life and extensive flexibility in dealing with different types of waste. The high specific power directly transferred by induction to the melt allows high operating temperatures and the cooling of the melter wall produces a solidified glass layer that protects the melter's inner wall from corrosion and high temperature effect (Fig. 1).

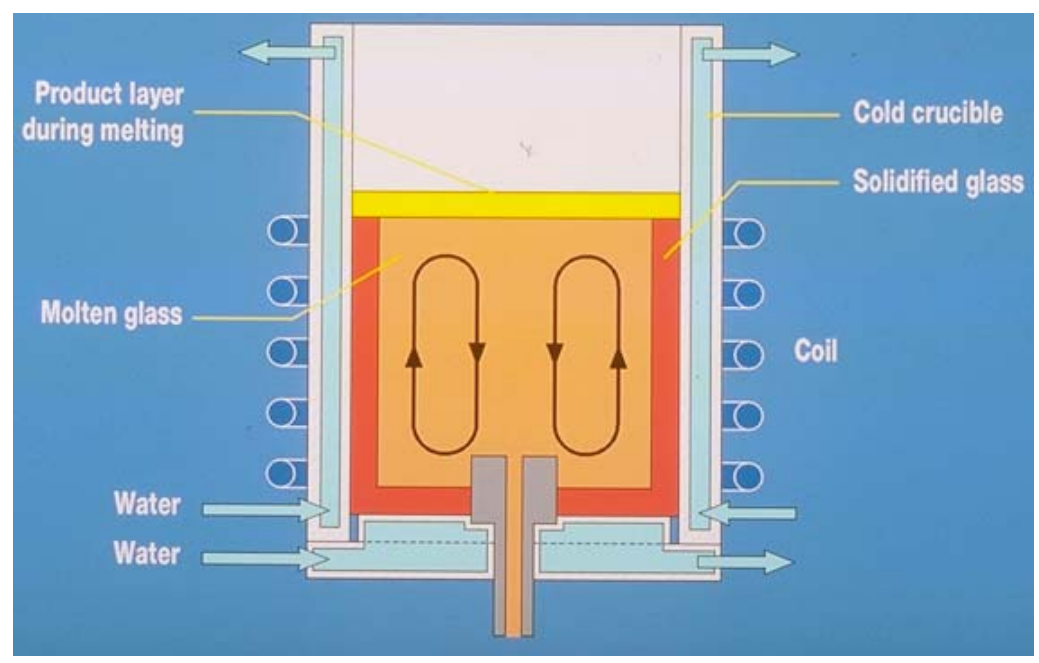

Fig. 1. Cold Crucible Melter Technology

To optimize the management of the UMo Project, a working group gathered COGEMA, CEA and SGN experts has been created to integrate from the outset :

- The industrial requirements and the operating and design Vitrification experiences ;

- The fundamental knowledge concerning glass formulation and properties, in particular in term of expected long term behaviour ;

- The improvement of the 2 step-vitrification process performed in the last 20 years (from the hot to the cold melter).

To prepare and support the replacement of one hot melters by a cold-crucible melter able to process this new matrix (still coupled to the calciner), in the existing R7 vitrification facility :

- A full-scale pilot has been implemented in the test hall of Marcoule and has been being used to perform the tests necessary for wasteform optimization and qualification ;

- Basic and details design studies have been performed.

The basic data associated to the UMo project were the following :

- The implementation of a CCM in one of the three R7 vitrification line ;

- The conservation of the 2 step-vitrification process, based on compact and modular technology, which permit a great flexibility regarding the nature of solutions to be vitrified as well as the treatment capacity (glass throughput) ;

- A maximum waste loading (oxide molybdenum content higher than $10 \mathrm{wt} \%$ ) to minimize the UMo vitrification campaign duration (a 5 year-period corresponding to the production of less than 800 glass canisters) and to reduce the final waste storage volume ;

- The renewal of the Universal Canister used in T7/R7 to contribute to an extended waste standardization and as a consequence optimise the waste management from the vitrification line to the interim storage. 
Several publications ${ }^{(1-3)}$ have been already presented in Tucson on the description and advantages of the CCM for various applications and matrix design. In the present paper, we will focus on the development and qualification concerning UMo glass formulation as well as the technology and process features. Some industrial and safety requirements and the engineering studies and results regarding implementation of the CCM in existing R7/T7 Vitrification cells are also detailed.

\section{GLASS FORMULATION DEVELOPMENT}

\section{General Method for Containment Glass Formulation}

Acceptance criteria requirements for the final material must first be defined to orient the glass formulation procedure ${ }^{(4)}$. The specifications determine the following :

- Standard waste-form composition and variation range,

- Process-related fabrication constraints,

- Required matrix properties after fabrication,

- Expected waste volume reduction factor.

This step identifies a range of vitreous material compositions suitable for incorporation of the waste elements. The composition range is selected on the basis of the expertise acquired by the CEA in waste containment glasses. The compositions within the selected range are tested to assess their potential and to select one or more compositions for optimization and more thorough characterization. The tests focus in particular on the processing temperature, the properties necessary to ensure satisfactory process control (e.g. thermal conductivity and electrical resistivity), the micro-homogeneity, the chemical durability determined by Soxhlet tests on glass coupons at $100^{\circ} \mathrm{C}$ and PCT tests at $90^{\circ} \mathrm{C}$ on powder samples in a closed system. Following this laboratory study of non-radioactive materials, in which the radioactive species are replaced by non-radioactive isotopes or surrogate elements, a reference glass is specified. The reference glass is validated by fabricating a non-radioactive sample in a pilot unit at a scale representative of the actual fabrication process.

A sensitivity study is then carried out to determine the impact of variations in certain parameter values on the feasibility of fabricating the matrix and on the characteristics of the final material. This study covers possible waste composition variations in particular. An experimentation plan methodology can be used if appropriate for this demonstration: in this approach a glass composition from within the range is related to its properties by interpolating the measurement results ${ }^{(5)}$. The operating range is validated by performing one or more fabrication tests in the vitrification pilot facility under the worst-case operating configurations.

The final phase of the formulation study necessary before accepting the containment matrix involves a long-term behavior assessment. These findings are intended to corroborate the chemical durability test results obtained during the previous studies; they are supplemented by studies of irradiation stability and an assessment of the long-term alteration phenomena liable to affect the material. Depending on the radioactive elements present in the waste and the properties of the matrix, it may be advisable to include an additional validation step in which the matrix is fabricated and characterized with radioactive waste samples ${ }^{(6)}$. 


\section{Formulation of a glass matrix for containment of UMo-MoSnAl solutions}

Considering elements present in the UMo-MoSnAl High level waste feed solutions, the molybdenum and phosphorus loading capacity of the glass is unquestionably decisive for the waste loading capability of the containment matrix. Molybdenum loading is limited to about $4 \mathrm{wt} \%$ in R7/T7 glass. At higher values a water-soluble segregated yellow molybdic phase could appear in the glass. Phosphorus cannot be loaded to above a few percent in this type of glass because it forms silicates liable to diminish the chemical durability of the residual glass. It was therefore decided to investigate a different composition range than R7/T7 glass also to take into account the radioactive specificity of UMo solution.

It was chosen to begin with a range based on $\mathrm{SiO}_{2}, \mathrm{Na}_{2} \mathrm{O}, \mathrm{Al}_{2} \mathrm{O}_{3}, \mathrm{P}_{2} \mathrm{O}_{5}, \mathrm{~B}_{2} \mathrm{O}_{3}$ and $\mathrm{MoO}_{3}$. Tests were also conducted with various additives : $\mathrm{CaO}$ to stabilize molybdenum in the form of durable calcium molybdate crystals, $\mathrm{ZrO}_{2}$ to enhance the chemical durability of the final glass, and $\mathrm{ZnO}$. The limits of the composition range were determined from the results obtained during CEA tests in the 1960s and 1970s with compositions capable of being fabricated at temperatures below $1200^{\circ} \mathrm{C}$; the target value is now between $1200^{\circ} \mathrm{C}$ and $1300^{\circ} \mathrm{C}$, however, made possible by the use of a cold crucible melter.

The following weight percentage composition range was investigated :

- $\mathrm{SiO}_{2} \quad: \quad 32-44$

- $\mathrm{Al}_{2} \mathrm{O}_{3} \quad: \quad<5$

- $\mathrm{B}_{2} \mathrm{O}_{3}: 15-22$

- $\mathrm{Na}_{2} \mathrm{O} \quad$ : 12

- $\mathrm{MoO}_{3} \quad: \quad 10-12$

- Tested additives: $\mathrm{CaO}, \mathrm{ZnO}, \mathrm{ZrO}_{2}$.

Over 100 glass samples were fabricated and characterized in this range. The results (Fig. 2) for each composition are normalized for the three constituents with the greatest impact on the final material within the studied range: $\mathrm{SiO}_{2}, \mathrm{Al}_{2} \mathrm{O}_{3}, \mathrm{P}_{2} \mathrm{O}_{5}$. Three glass families were identified within the domain, in addition to highly refractory matrices unsuitable for fabrication at $1300^{\circ} \mathrm{C}$ :

- Glasses that are translucent after quenching,

- Opaque glasses,

- Macroscopically heterogeneous matrices.

SUMo1-10a and SUMo2-12a glasses from the first and second families, respectively, were selected for further optimization, together with reduced $\mathrm{SPNM}^{\prime}$ glass. The qualities of reduced $\mathrm{SPNM}^{\prime}$ glass for vitrification of UMo-MoSnAl solutions were observed during another formulation study ; although this composition is not part of the selection range, its advantageous chemical durability and viscosity characteristics are related to the oxidation state of molybdenum, which is reduced to $+\mathrm{IV}^{(7)}$. Following this optimization and characterization phase, SUMo2-12c glass (optimized from SUMo2-12a) was selected as the reference formulation. The compositions of these four glasses are indicated in Table I. The reference glass was also fabricated in a pilot cold crucible melter at Marcoule (scale one copy of the further hot Vitrification cell). Samples were taken at different positions along a vertical cross section of the canister. 


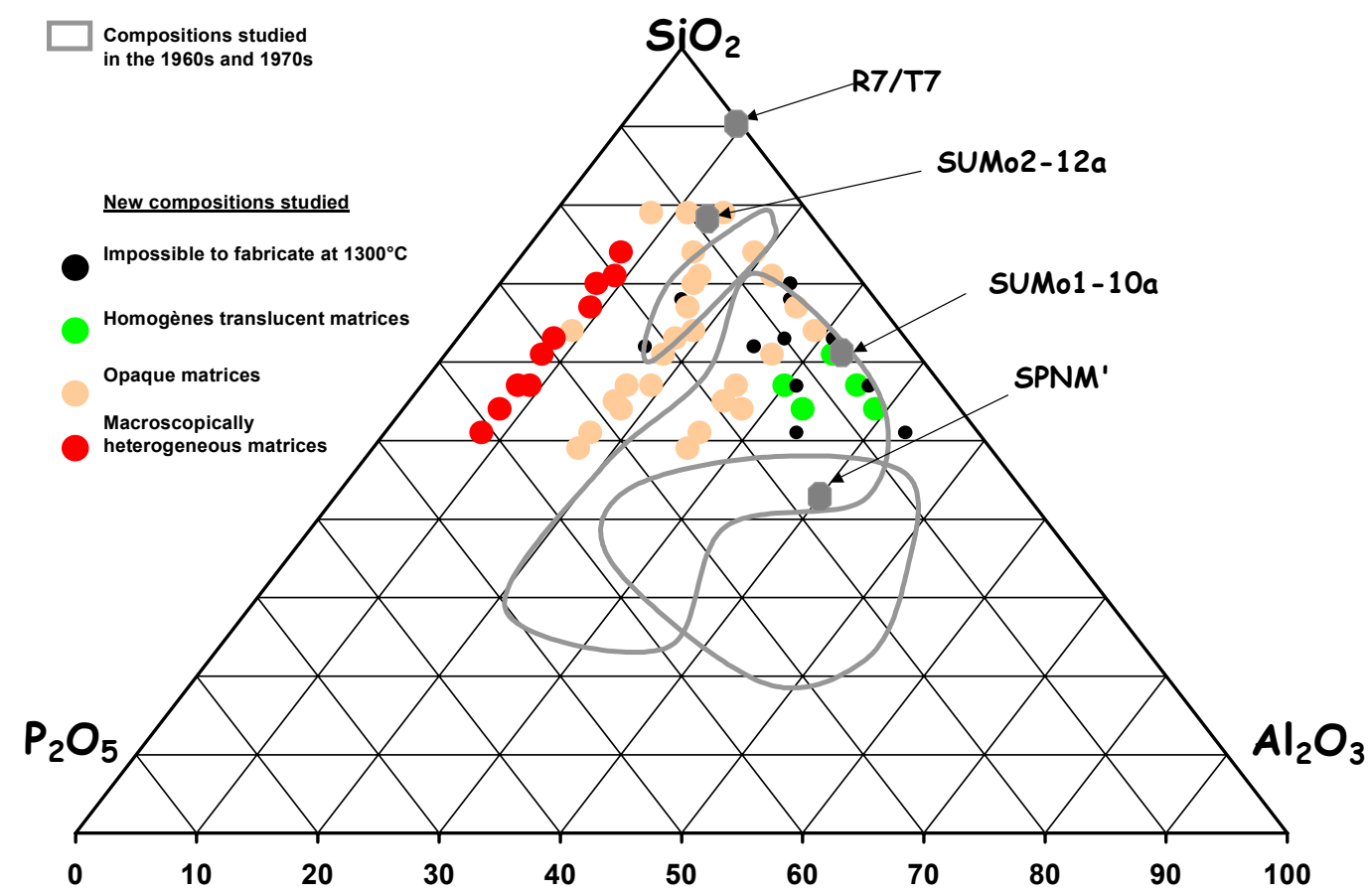

Fig. 2. Glass composition range

\begin{tabular}{|l|l|l|l|l|}
\cline { 2 - 5 } \multicolumn{1}{c|}{} & SUMo2-12a & SUMo2-12c & SUMO1-10a & $\begin{array}{c}\text { SPNM' } \\
\text { reduced }\end{array}$ \\
\hline $\mathbf{S i O}_{2}$ & $\mathbf{3 5 , 0 9}$ & $\mathbf{3 5 , 9 9}$ & $\mathbf{3 3 , 1 3}$ & $\mathbf{2 1 , 3 4}$ \\
\hline $\mathbf{N a}_{\mathbf{2}} \mathbf{O}$ & $\mathbf{8 , 5 5}$ & $\mathbf{8 , 7 9}$ & $\mathbf{1 2 , 0 5}$ & $\mathbf{1 0 , 8 8}$ \\
\hline $\mathbf{B}_{\mathbf{2}} \mathbf{O}_{\mathbf{3}}$ & $\mathbf{1 5 , 1 6}$ & $\mathbf{1 2 , 9 6}$ & $\mathbf{2 0 , 0 8}$ & $\mathbf{1 8 , 3 8}$ \\
\hline $\mathbf{A l}_{\mathbf{2}} \mathbf{O}_{\mathbf{3}}$ & $\mathbf{6 , 0 3}$ & $\mathbf{6 , 1 8}$ & $\mathbf{2 0 , 0 8}$ & $\mathbf{1 9 , 6 4}$ \\
\hline $\mathbf{P}_{\mathbf{2}} \mathbf{O}_{\mathbf{5}}$ & $\mathbf{3 , 7 0}$ & $\mathbf{3 , 6 9}$ & $\mathbf{3 , 1 0}$ & $\mathbf{8 , 4 6}$ \\
\hline $\mathrm{MoO}_{3}$ & 12,00 & 12,00 & 10,00 & 16,00 \\
\hline $\mathrm{ZnO}$ & 5,70 & 5,62 & 0,00 & 0,00 \\
\hline $\mathrm{ZrO}{ }_{2}$ & 7,00 & 7,14 & 0,00 & 0,00 \\
\hline $\mathrm{CaO}$ & 4,70 & 5,67 & 0,00 & 0,00 \\
\hline others & 2,06 & 1,96 & 1,55 & 5,30 \\
\hline total & 100,00 & 100,00 & 100,00 & 100,00 \\
\hline
\end{tabular}

Table I. Glass compositions (wt\%) 
The reference UMo glass, SUMo2-12c, is a vitreous material fabricated at $1250^{\circ} \mathrm{C}$. It is opaque, as it contains microbeads uniformly distributed in the glass. The microbeads containing molybdenum, phosphorus, calcium and zinc are capable of stabilizing molybdenum and phosphorus, which are difficult to incorporate in a silicate network. Some of the beads appear to be crystallized and contain calcium molybdate.

Chemical durability tests in Soxhlet mode at $100^{\circ} \mathrm{C}$ yielded $r_{0}$ values of $3 \mathrm{~g} \cdot \mathrm{m}^{-2} \mathrm{~d}^{-1}$; PCT tests in pure water at $90^{\circ} \mathrm{C}$ at a glass-surface-area-to-water-volume ratio of $80 \mathrm{~cm}^{-1}$ indicated a maximum boron leach rate of $2.5 .10^{-2} \mathrm{~g} \cdot \mathrm{m}^{-2} \mathrm{~d}^{-1}$ between 91 and 120 days. The molten glass properties are also compatible with fabrication in a cold crucible melter : a viscosity of $38 \mathrm{dPa} \cdot \mathrm{s}$ at $1250^{\circ} \mathrm{C}$ and an electrical resistivity of about $6 \Omega . \mathrm{cm}$ at $1250^{\circ} \mathrm{C}$. The glass fabricated in the laboratory based on the cooling scenarios expected in the waste canister exhibited the same properties as the glass sampled from the canister.

Considering the possible amplitude of the variations affecting the matrix fabrication parameters described above, the parameters determining the limits of the acceptability range are the molybdenum and phosphorus concentrations in the final glass. For the purposes of this formulation study, the sensitivity study have thus consisted in determining the extreme acceptable variations for these three parameters.

\section{TECHNOLOGICAL AND PROCESS QUALIFICATION}

\section{General approach}

In the continuity and as an essential support of the qualification of the final process and glass matrix for industrial operation, technological tests on scale one copy of the further industrial vitrification have been performed. The technological test objectives are the following :

- To produce a specified material under representative process conditions and verify its conformity with the laboratory-scale qualification test results ;

- To determine a process operating range characterized by the process control parameters and covering all possible operating conditions :

- nominal operation (including transient modes),

- maximum throughput,

- degraded operating modes (useful for safety analysis and demonstration);

- To validate the equipment concepts, verify the integration of all the components, and validate the material selection.

\section{Specific features}

The distinctive aspect of the UMo application lies in the integration of a cold crucible melter into an existing very high-level waste vitrification line already operating under active conditions. It is thus essential to guarantee proper operation of the melter from the first utilization. A full-scale prototype was used to ensure maximum representativeness of the test conditions and allow accurate determination of directly applicable process control parameters.

The COGEMA operators will be early trained in melter control procedures by associating them with the prototype tests ; the constitution of COGEMA operators and CEA R\&D team allows :

- On one hand, to have operational technicians from the moment of active startup ;

- On the other hand, to have technological development and process procedure consistent with industrial constraints and requirements. 
Moreover, the full-scale prototype used to develop and qualify the technology, process and matrix will be used for continued support of the plant operator, allowing the facilities and products to be optimized and upgraded after beginning of active operation.

\section{Major choices and constraints}

The cold crucible melter was substituted in the process for the existing metal pot beneath the calciner. It was designed to meet environmental and process constraints : for example, the canister is still filled by pouring two successive $200 \mathrm{~kg}$ melts.

The CCM operating constraints were extended to anticipate the processing of UOX1 and UOX2 solutions coming from La Hague reprocessing activities of spent fuel, that will also be vitrified in this line in the cold crucible melter after UMo operation : more generally, the use of the cold crucible melter to produce a containment glass complies with and extends the provisions previously established to obtain and guarantee the glass quality (based on the requirements of the existing quality assurance and quality control programs).

The use of the CCM has no effect on the other process equipment (calciner and off-gas treatment); the overall performance of the process line complies with the initial design rating of the vitrification line.

The choice of a cylindrical cold crucible was dictated by layout constraints in the existing pouring cell : it replaces the existing hot induction melting pot, and the bottom of the melter must mate with the existing connection in the cell. The pouring orifice is therefore situated in the same position as the pouring nozzle in the former metal melting pot.

The choice of conserving a 2-step process (separation of the calcining and melting function, Fig. 3) was justified by compliance with the basic concept implemented by COGEMA for all its equipment (compact, modular design, allowing easy maintenance and resulting in a small volume of technological and secondary waste) and by the objective of minimizing the complications and investment cost of incorporating the unit in the existing line. Moreover, the solid feed provision could allow UMo glass production capacity to be doubled for the same diameter.

\section{Continuous Vitrification Process}
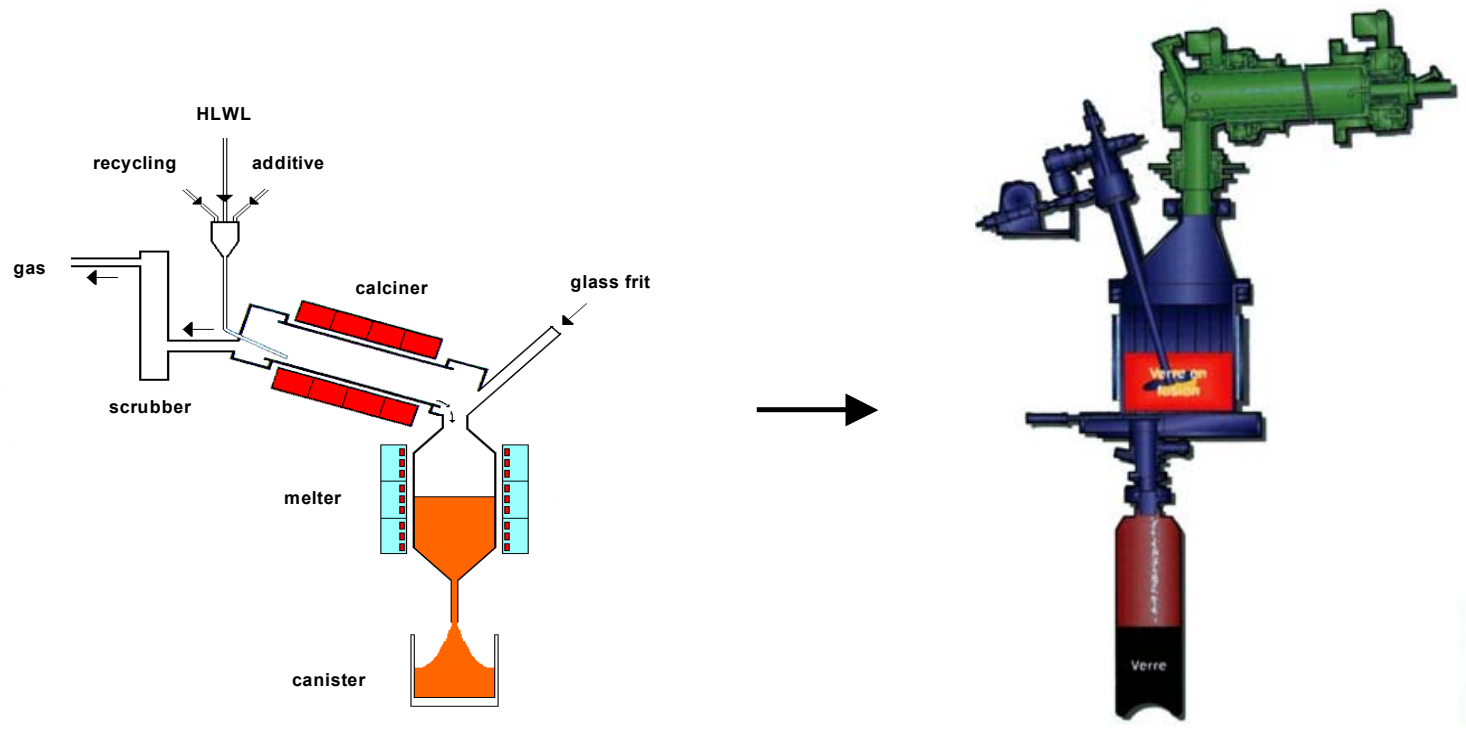

Fig. 3. Two-step vitrification process 
Thermal data obtained for the melter by modeling and measurements show a maximum power density in a zone near the skull of solidified glass, resulting in high temperatures. The temperature is also high at the top of the melt because of strong convection currents. Moreover, the temperature around the crucible periphery is lowered by the cooled sectors.

The glass melt is mechanically stirred to ensure satisfactory thermal homogeneity. A cooled, retractable stirring device was designed for this purpose. Its tilt angle allows for the size of the lower end of the calciner.

The molten glass temperature is an important parameter for ensuring product quality, particularly by maintaining a minimum fabrication temperature to guarantee a suitable vitreous state. The glass level in the melter is continuously monitored : this is a safety-related parameter for filling the canister.

The instrumentation is a critical aspect that must be capable of ensuring continuous measurement, and resistance to irradiation, magnetic fields, and high temperatures. The basic principle is to ensure interchangeability without dismantling the melter, and is the result of a specific development and qualification program.

\section{Melter Design}

The melter design complies with all remote maintenance principles applicable in COGEMA vitrification cells ; it is a compact one-piece unit to simplify installation and removal. Its light weight $(950 \mathrm{~kg})$ and 'cold' design ensure optimization of the ultimate technological and secondary waste volume and suitability for incorporation in the existing waste treatment processes at La Hague.

A $400 \mathrm{~kW}$ generator operating at a frequency of $300 \mathrm{kHz}$ supplies the power necessary to fabricate the glass.

The inner diameter of the cold crucible melter is $650 \mathrm{~mm}$ (Fig. 4).

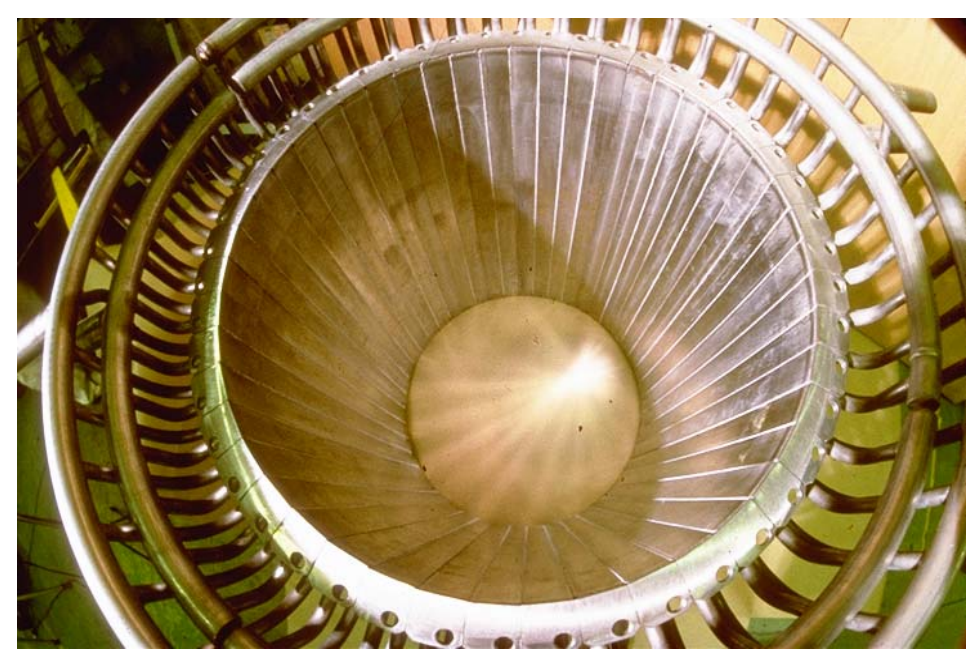

Fig. 4. Inner view of the Cold Crucible Melter 


\section{Process features investigated}

The calcining conditions for UMo solutions were adjusted according to their particular composition (high Mo and $\mathrm{P}$ concentrations), notably through the use of a calcining additive. Specific technological development work was carried out not only on the equipment interface provisions but also on the particle separator to take into account the heavily loaded process solutions.

The UMo glass resistivity is compatible with the fabrication in a cold crucible melter; optimizing the overall thermal conductivity appreciably, diminished radiated heat loss to the melter walls. This work was carried out in close collaboration with the teams responsible for formulating the glass to maintain the final quality of the glass product.

The stirring parameters (impeller blade profile, rotation speed and direction) were optimized to ensure thermal homogeneity while maintaining a cold layer on the surface of the melt. Despite the high temperature of the molten glass $\left(1250^{\circ} \mathrm{C}\right)$, this layer limited the quantity of volatilized material.

The decontamination factors were determined for the equipment items and compliant with La Hague standard.

The wall temperature reached by the glass canister on pouring allowed the use of R7T7-type glass canisters.

The process control parameters were determined for normal operation and for transient conditions (water ingress, replacement of an instrumentation probe, etc.).

\section{Technological development}

The organic materials used for electrical insulation were selected and characterized for their irradiation performance allowing for the radioactivity constraints not only of UMo solutions but also of R7T7 solutions, which are 50 to 100 times more active.

Week reference tests were carried out under production and nominal feed conditions to determine performance in terms of process control and operation :

- Adjusted solution feed rate : $401 / \mathrm{h}$,

- Solid matter in solution : $154 \mathrm{~g} / \mathrm{l}$,

- Recycling rate $: 10 \mathrm{l} / \mathrm{h}$,

- Glass production rate : $25 \mathrm{~kg} / \mathrm{h}$ (can be increased to $40 \mathrm{~kg} / \mathrm{h}$ ).

The principal results obtained concerned the provisions for controlling :

- Glass level measurement,

- Continuous glass temperature measurement,

- Glass temperature regulation,

- Automatic pouring cycle,

- Major process parameters related to glass quality.

\section{Work to be completed}

Degraded operation tests (referred to as "ultimate" tests because they can jeopardize the integrity of the cold crucible melter, e.g. unexpected massive inflow of water in the crucible, cooling system failure, etc.) are scheduled.

Nevertheless similar tests have already been carried out during other programs with no significant effect on the crucible. 


\section{IMPLEMENTATION OF A CCM IN A LA HAGUE HOT VITRIFICATION CELL}

\section{A challenge for engineering}

As mentioned before, the CCM technology will be deployed at La Hague, in one existing vitrification cell, to process specific corrosive, high viscosity material in the near future. Because of high radiological constraints - the surrounding dose rate in the vitrification cell is about $50 \mathrm{~Gy} / \mathrm{h}$ - the implementation of a CCM constitute a challenge for engineering as all modifications have to be performed remotely.

In addition, the construction phase on the chosen vitrification line of the R7 facility must be as short as possible in order to minimize the down-time of the production mean. The new equipment must also be compatible with actual layout of the cell to minimize the modifications of the existing equipment (calciner, off-gas treatment system, glass pouring system).

\section{Design studies for engineering}

Basic and detailed design studies have been performed by SGN from 1999 to 2001 . The main constraints that have been taken into account were :

- The specificity of the layout in the vitrification cell ;

- The radiological constraints (minimizing the dose to the workers);

- The design features defined by CEA for the main equipment (CCM, inductor coil, HF generator,...) ;

- The 20 years of industrial vitrification experience.

The scope of these studies mainly includes :

- Process studies (e.g. definition of nominal process diagram, sizing of the utilities ...);

- Safety assessment studies;

- Mechanical studies (e.g. impact of the layout constraints on the main equipment design, determination of well fitted sub-components configuration, checking remote maintenance possibilities for the CCM and associated equipment...);

- Electrical studies (e.g. sizing of the HF system, impact of the new HF system on the cross-wall device, Electromagnetic compatibility arrangements,...);

- Lay out studies : modification of the existing utilities in R7 (electricity, cooling capabilities...).

Thanks to the compactness of the CCM technology and the versatility of the hot cells design, these studies have shown the feasibility of the implementation of a $650 \mathrm{~mm}$ in diameter CCM in R7. Based on these studies, modifications of the existing vitrification cell were proposed and a schedule was established for engineering, procurement, building, testing, and starting the new installation. This schedule, validated by the future R7 operators, integrate the experience gained by SGN and COGEMA during the R7 facility upgrading in $1994-1995$.

One of the conclusions of these studies lead also to the definition of a nuclearization program including additional tests and studies. This nuclearization program is performed by integrated teams including R\&T, engineering and industrial operators. 


\section{Nuclearization program}

The aim of this program is to perform complementary tests and studies in order to adapt the final design of equipment to be implemented at La Hague to the nuclear and industrial environment of the vitrification cell. It mainly focuses on choice of material under thermal, mechanical and high radiation constraints and on option selection for the design of specific sub-component of the CCM (cooling valve device concept, mechanical stirring device, measurement system calibration).

The choice of the material to be used for the electrical insulation between the stainless steel segments can be given as one of the most representative example of the nuclearization approach. Firstly, few different materials were selected. This first selection process was based on an assessment of the physical properties of possible candidate materials derived from CEA background information (use on various CCM pilots, bibliographical studies on degradation of such material under irradiation) and from knowledge gained during the operation of the La Hague vitrification facility. The selected materials have then been characterized (mechanical, electrical properties) after irradiation doses corresponding to three different scenario :

- $410^{6} \mathrm{~Gy}$ corresponding to vitrification of UMo solution during about 4 years ;

- $310^{7}$ Gy corresponding to vitrification of R7 solution during about 2 years ;

- $710^{7}$ Gy corresponding to vitrification of R7 solution during about 4 years.

Measurement of physical properties after each irradiation doses allows the best choice for insulator material.

On all these subjects, the complementary tests and studies to be performed will allow option selection and therefore enable to define the best configuration to be implemented in the R7 facility.

\section{Safety assessment}

A safety assessment study has been performed by SGN in order to identify and analyze the main risks associated to the use of a CCM at La Hague.

As a result of the safety analysis, a specific design approach has been developed for the following two examples :

- Glass draining from CCM : in order to avoid a possible overflow of glass from the canister during the pouring operation, two valves (one on the top of the other) will be implemented and they will be controlled by two independent system assessing the amount of glass poured in the canister (canister weight, glass level in the CCM) ;

- CCM cooling : Tests were performed to assess the damage suffered by a CCM when the CCM cooling is stopped. The maximum temperature measured was $370^{\circ} \mathrm{C}$ with an initial glass temperature of $1200^{\circ} \mathrm{C}$. As a result of this thermal transient, no glass leakage was observed and only limited damage damages to the structure were observed. In order to limit theses damages, the cooling system should be designed in order to provide a high level of reliability: this is achieved by a redundant cooling system and a surge water tank. 


\section{CONCLUSION}

COGEMA has been operating industrial HLW vitrification facilities successfully for over 20 years. The feedback from hot operation, the long-term R\&D programs conducted with the CEA and the full support of vitrification engineering leaded by SGN, have helped to continuously improve all aspects of the vitrification (glass formulation, process, associated technologies, operations and maintenance).

The project to vitrify very corrosive HALW solution stored at present time in La Hague tanks is a great example of this complementarity.

The association of R\&D methodology and development to define and qualify a glass matrix and a process (CCM two step vitrification process), the integration - as basic data - of the industrial constraints and requirement and the feedback of engineering to implement a technology in existing hot cell are the fundamental basis of this project to provide a cost effective conditioning solution.

The feature of UMo Solution (high content en molybdenum and phosphorus), the objective to minimize the final waste volume as reasonably achievable with respect to a final disposal acceptance, and the requirement to treat this solution in COGEMA existing vitrification facility have been taken into account and have leaded to develop a high waste loading matrix which take benefit from Cold Crucible Melter advantages and divided by factor four the number of canister to be produced.

The formulation and process qualification program have been managed on laboratories and pilot scale.

A full scale copy of the industrial vitrification process has been used for the R\&D program but also to train operators and to validate design options.

1. R. DO QUANG, A. JOUAN, G. MEHLMAN - "Major breakthroughs in high level waste vitrification", Waste Management 2000, Tucson.

2. C. LADIRAT, C. FILLET, R. DO QUANG, G. MEHLMAN, T. FLAMENT, "The Cold-Crucible Melter : a key technology for the DOE cleanup effort", Waste Management 2001, Tucson.

3. E. NICAISE, C. VEYER, S. GOETGHEBEUR, P.-R HRMA, E.-V. MORREY, G.-L. SMITH, J.-D. VIENNA, J.-L. DUSSOSSOY, C. LADIRAT, A. LEDOUX, M. PUYOU, "Hanford High Level Waste Processing in a Cold Crucible Melter : Test Results obtained in the framework of TWRS-P Contract", Waste Management 1999, Tucson.

4. V. PETITJEAN, C.FILLET, R. BOEN, C. VEYER, T. FLAMENT - "Development of Vitrification process and glass formulation for nuclear waste conditioning", Waste Management 2002, Tucson.

5. D. MATHIEU, R. PHAN TAN LUU, NEMROD software package, LPRAI Marseille.

6. J.M. BART, J.G. CHARBONNEL, S. PEUGET, V. BROUDIC, C. JEGOU, T. ADVOCAT, "A new research facility devoted to highly radioactive materials", Atalante 2000, Avignon, France (October 2000).

7. O. PINET, E. BAUDREY, J.L. DUSSOSSOY, C. FILLET, J.F. HOLLEBECQUE, "Redox effect on waste containment glass properties: case of a borosilicate glass containing $16 \mathrm{wt} \% \mathrm{MoO}_{3}$ ”, Glass Technology, Vol. 43C 2002, Proc. XIX Int. Conf. Glass, Edinburgh (July 1-6, 2001). 